Revista lus et Praxis, Año 24, No 2, 2018, pp. 513 - 548

ISSN 0717 - 2877

Universidad de Talca - Facultad de Ciencias Jurídicas y Sociales

El régimen de responsabilidad disciplinaria de los jueces chilenos

Andrés Bordalí Salamanca

Trabajo recibido el 14 de abril de 2017 y aprobado el 11 de abril de 2018

\title{
El régimen de responsabilidad disciplinaria de los jueces chilenos y su inadecuación a las exigencias constitucionales
}

THE UNCONSTITUTIONALITY OF THE DISCIPLINARY REGIME OF JUDGES IN CHILE

Andrés Bordalí Salamanca*

RESUMEN

El trabajo analiza el régimen de responsabilidad disciplinaria de los jueces chilenos regulado tanto en el Código Orgánico de Tribunales como en los Autos Acordados que ha dictado la Corte Suprema. La tesis propuesta sostiene que la aplicación de sanciones a los jueces debe hacerse bajo el principio de legalidad y tipicidad y en un procedimiento jurisdiccional que respete todas las garantías de un debido proceso constitucional. Bajo esa óptica se concluye que la regulación chilena vigente no respeta esas garantías constitucionales.

ABSTRACT

This paper analyzes the regime of disciplinary responsibility of Chilean judges regulated both in the 'Código Orgánico de Tribunales' and in the 'Autos acordados' of the Supreme Court of Justice. The hypothesis argues that the application of sanctions to judges must be respectfull of certain constitutional garantees. First, the principles of legality and typicity and, second, all the elements of a constitutional due process. It is concluded that the current Chilean regulation of the disciplinary responsibility of the judges contravenes these guarantees.

Palabras Claves

Responsabilidad disciplinaria de jueces - independencia judicial - debido proceso

KEY WORDS

Disciplinary responsibility of judges-judicial independence-due process

\section{Introducción}

Uno de los pilares estructurales del Estado de Derecho es la consagración de un Poder Judicial separado de los órganos políticos, esto es del Gobierno y el Parlamento. Además, se acostumbra a reconocer a ese Poder Judicial independencia respecto de esos poderes políticos. Para hacer operativa la independencia judicial se necesita que los jueces no sean nombrados en exclusiva por uno de los poderes políticos del Estado, con especial consideración del Ejecutivo. Además, se requiere reconocer la inamovilidad de los jueces en sus cargos.

\footnotetext{
* Abogado, Doctor en Derecho, profesor titular en la Facultad de Ciencias Jurídicas y Sociales de la Universidad Austral de Chile, Valdivia, Chile. Correo electrónico: abordali@uach.cl.
} 
Sin embargo, un juez independiente amparado por el principio de inamovilidad constituye un poder muy fuerte y, por ello, se dice que el contrapunto de la independencia judicial es el de la responsabilidad. No hay Estado de Derecho que se pueda sostener sin que los jueces sean responsables en su actuar ${ }^{1}$.

La ecuación perfecta en esta materia será lograr un juez lo más independiente posible, pero que a su vez responda por sus actos dolosos, negligentes o inadecuados. Sin embargo, el óptimo de esta ecuación constituye un verdadero nudo gordiano de todo sistema judicial. Se trata de lograr que los jueces no tengan una dependencia excesiva del Gobierno y del poder legislativo, pero tampoco que esa independencia derive en la creación de un cuerpo estamental impermeable a los valores y necesidades sociales.

En el derecho comparado los sistemas de responsabilidad de los jueces se articulan sobre un modelo que basa la responsabilidad en una de carácter político. Me refiero a la institución del impeachment del derecho anglosajón. Y luego está el modelo continental de origen francés que lo centra en un sistema de responsabilidad de tipo disciplinario ${ }^{2}$.

Pero en el derecho continental no siempre el sistema se ha basado en la responsabilidad disciplinaria. Se puede señalar que en el derecho europeo han existido dos modelos. Uno afirmado en el derecho romano y luego en el derecho comunal medieval que sitúa al juez en un nivel de máxima independencia respecto al poder político, pero que crea un importante control externo de su actuar y su profesionalidad, a través de un control vía responsabilidad civil, sin que existan controles de tipo disciplinario. El otro modelo se afirma en el carácter estatal del derecho y se desarrolla sobre todo a partir del siglo $\mathrm{XVIII}$, en el cual se concibe al juez como un funcionario del Estado, inmune a un control por las partes, pero que se encuentra sujeto a un riguroso control interno de tipo disciplinario ${ }^{3}$. Es este el modelo que termina por prevalecer en el derecho europeo continental, coherente con la formación del Estado absoluto y luego el Estado que surge después de la Revolución francesa con Napoleón en el poder. La responsabilidad disciplinaria es la principal forma de control sobre los jueces en los estados europeos.

Sin embargo, el modelo judicial burocrático que se diseñó en Europa desde el Estado prusiano y luego napoleónico, con fuerte control disciplinario sobre

\footnotetext{
1 Bordalí (2003), p. 163.

${ }^{2}$ No se puede aseverar que los jueces europeos continentales no tengan ningún tipo de responsabilidad en términos políticos. Depende de cada Estado. Por regla general se puede decir que no existe responsabilidad política de los jueces continentales. Pero ello no excluye ciertos controles parlamentarios o ministeriales sobre los jueces, como ocurriría en Alemania por ejemplo. SCHEFOld (2004), p. 259.

${ }^{3}$ Graziano (2013), p. 283.
} 
sus jueces funcionarios, ha variado sustancialmente. En efecto, desde la formación del Estado moderno, el control jerárquico de los jueces europeos lo desempeñaba el Ejecutivo por medio del Ministro de Justicia. Desde fines de la Segunda Guerra Mundial esas competencias pasaron al órgano de gobierno del Poder Judicial, esto es el Consejo General o Superior de la Magistratura que existe en países como España, Francia e Italia, entre otros.

A esa responsabilidad disciplinaria la gran mayoría de los estados europeos agrega la responsabilidad penal y la civil del juez que pueda derivarse de un delito, así como en algunos casos, la del Estado por los daños que causa el juez funcionario.

Existe un relativo consenso en que los jueces deben responder por los ilícitos penales en que puedan incurrir con ocasión de su actividad y de los daños patrimoniales y extrapatrimoniales causados al ciudadano, aunque en esta última situación se utiliza en muchos casos, complementariamente, la responsabilidad del Estado por el juez funcionario. La duda se da por tanto respecto al régimen adecuado de responsabilidad política y disciplinaria; sobre si corresponde tenerlos y en caso afirmativo, bajo qué modalidades.

En relación a la responsabilidad política, existen bastantes voces en el derecho continental que señalan que ella no se puede aplicar respecto de los jueces. En efecto, se señala que éstos, al no representar a ninguna fuerza política, ni mayoritaria ni minoritaria, no pueden quedar expuestos a un control político ${ }^{4}$. En otras ocasiones se dice que en el marco de la separación de los poderes de un Estado democrático, la jurisdicción se la concibe como una potestad de control antes que un poder de dirección política. Por ello no pueden quedar los jueces sometidos al poder político de los otros poderes ${ }^{5}$. En países como Italia, se afirma que el derecho no prevé respecto de los jueces ningún tipo de responsabilidad política ${ }^{6}$.

En relación a la responsabilidad disciplinaria, las fórmulas avanzadas han sido de varios signos. Se ha propuesto en algunos casos eliminar todo tipo de control disciplinario y confiar la actuación de los jueces a un control externo de tipo social por intermedio de la opinión pública.

En otros casos, se propone mantener la responsabilidad disciplinaria pero bajo condición de reestructurarla profundamente ${ }^{7}$. Esa reestructuración apunta

\footnotetext{
4 Véase sobre este aspecto Ferrajol (1997), pp. 595 y ss.; Picardi (1979), p. 1.498.

5 Graziano (2013), p. 281; Bairati (2013), p. 16.

6 Bartole (2008), p. 72.

7 PiCARDI (1979), p. 1.501.
} 
a hacer compatible ese tipo de responsabilidad con las garantías de un derecho sancionador y del debido proceso.

En el derecho chileno tenemos que preguntarnos si el sistema de responsabilidad disciplinaria de los jueces se ajusta a las garantías sustanciales y luego a las de un debido proceso que garantizan la Constitución y los tratados internacionales. Mi hipótesis de trabajo intentará demostrar que los jueces chilenos están regidos por un estatuto jurídico que no respeta las garantías aludidas. Existen preceptos jurídicos en la propia Constitución que necesitan de reforma por afectar el principio constitucional de independencia judicial. A su vez, el Código Orgánico de Tribunales no se ajusta a los requerimientos constitucionales y a los contenidos en tratados internacionales sobre derechos humanos vigentes en el país. La materia del derecho disciplinario judicial requiere por tanto de reformas constitucionales y legales.

\section{La responsabilidad jurídica de los jueces chilenos}

La Constitución de 1980 (en adelante CPR), se refiere en seis artículos a la responsabilidad jurídica de los jueces chilenos. Estos son los artículos $32 \mathrm{~N}^{\circ} 13$; $52 \mathrm{~N}^{\circ} 2$ c); $53 \mathrm{~N}^{\circ} 1 ; 79 ; 80$ inciso $3^{\circ}$ y 82.

Cuando se habla de una responsabilidad jurídica de los jueces se hace referencia a que se llama a los jueces a responder por un comportamiento contrario a una prescripción jurídica. El juez deberá ser culpable de ese comportamiento. "sin culpa no hay responsabilidad y sin responsabilidad no hay sanción" ${ }^{8}$.

Un análisis de los preceptos constitucionales citados trae como resultado que los jueces chilenos tienen un complejo sistema de responsabilidad jurídica. En efecto, la Constitución establece que los jueces responderán disciplinaria y penalmente. Tratándose de ministros de los tribunales superiores de justicia, además tendrán una responsabilidad de tipo político a través de un sistema de impeachment ${ }^{9}$. Quedará a criterio del legislador determinar si a esa responsabilidad penal agrega una civil derivada del delito, cuestión que en la legislación chilena vigente ocurre.

De este modo, se puede concluir que las responsabilidades política, penal y disciplinaria de los jueces chilenos se imponen constitucionalmente. El legislador ordinario no podría derogar alguna de estas formas de responsabilidad exigidas constitucionalmente.

${ }^{8}$ Rentería (2002), p. 137.

${ }^{9}$ Existe controversia sobre cómo considerar a la responsabilidad política, si como una especie de responsabilidad jurídica o no jurídica. Todo depende si existiese una formulación normativa concreta. Vid. Rentería (2002), p. 154. 
Entrando a analizar nuestra realidad, hay que señalar que la ecuación independencia-responsabilidad de los funcionarios judiciales chilenos ha sido resuelta en favor de la responsabilidad por sobre la independencia, generando un modelo quizá único en su género. En efecto, el sistema chileno de responsabilidad judicial parte de la responsabilidad penal por los delitos funcionarios (arts. 79 CPR y 324 y siguientes Código Orgánico de Tribunales -en adelante COT-), para reconocer también una responsabilidad civil individual propia del juez profesional del medioevo ${ }^{10}$ (arts. 325 y siguientes COT), pero agregando la responsabilidad disciplinaria (arts. 82 CPR y 530 y siguientes COT) cuyo origen se remonta a la Alemania del siglo XVI y que logra su mayor significación en el siglo XVIII en el Codex Marchicus de Federico el Grande de 1748, desde donde emerge la metáfora del regimiento con relación al orden judicial, es decir, donde se articula a los fines del Imperio un orden judicial basado en el mismo principio jerárquico utilizado en el ejército. Ese principio luego será recogido con gran éxito por Napoleón en Francia ${ }^{11}$.

Pero no siendo todo ello suficiente, la Constitución de 1980 establece la responsabilidad política o constitucional de los magistrados de los tribunales superiores de justicia (art. 52 2) letra c) en relación con el 53 1) CPR), recogiendo así el sistema del impeachment del derecho anglosajón.

A todo ello se agrega por decisión del legislador ordinario el sistema de las visitas ordinarias a los tribunales (arts. 553 y siguientes COT), que ya practicaban los jueces alemanes en el siglo $\mathrm{XV}^{12}$.

Todo ello viene a significar que el derecho chileno, en vez de optar por un modelo anglosajón o continental de responsabilidad judicial, sumó ambos modelos, sometiendo al juez chileno seguramente al más exhaustivo sistema de responsabilidades de todo el derecho comparado. Los ministros de los tribunales superiores de justicia quedan a merced de los que decidan las mayorías políticas en el Congreso Nacional. A su vez, los jueces de lo demás tribunales que forman parte del Poder Judicial están sometidos al control disciplinario que pueden hacer sus superiores jerárquicos, esto es, las Cortes de Apelaciones y la Corte Suprema.

\section{La responsabilidad disciplinaria de los jueces chilenos}

\subsection{Responsabilidad penal, disciplinaria y ética de los jueces}

Un primer asunto que se debe deslindar en el tema de la responsabilidad disciplinaria de los jueces chilenos es la relación entre responsabilidad disciplinaria,

\footnotetext{
10 Para un estudio de la responsabilidad profesional del juez medieval PICARDI (1979), pp. 1.488 y ss.

11 Giuliani y Picardi (1995), p. 45.

12 Giuliani y Picardi (1995), p. 40.
} 
responsabilidad penal y control o responsabilidad ética. Y existe además otro aspecto a considerar, referido a determinar si estamos en una actividad de tipo jurisdiccional (jurisdicción disciplinaria) o bien en una modalidad de derecho administrativo sancionador.

Veamos los primeros deslindes. La responsabilidad disciplinaria se ocupa del buen funcionamiento de un determinado órgano desde una perspectiva interna. Y la responsabilidad disciplinaria de los jueces habrá de entenderse referida a sancionar aquellas actuaciones ilícitas del juez cuando ejerce jurisdicción. Se diferencia entonces de la responsabilidad penal, pues ésta tiene por definición una proyección social y general, externa al órgano público. Por ello se sancionan aquellas conductas que afectan los bienes jurídicos más preciados por la comunidad.

Y se diferencia la responsabilidad disciplinaria de un control ético ${ }^{13}$, pues este último establece parámetros de conducta muy altos, superiores a lo establecido legalmente, en general con un carácter prospectivo, dando así pautas de un comportamiento ideal del funcionario hacia el futuro. La responsabilidad disciplinaria y las declaraciones de principios éticos o código de buenas prácticas presentan varias diferencias. Se diferencian por autoría, contenido y la forma en que se concretarían.

Los códigos éticos responden a una lógica de autocontrol y autorregulación; una deontología profesional. Un código ético "ofrece a los jueces respuestas claras a preguntas de deontología profesional; informa a los ciudadanos de las conductas esperables por parte de los jueces y garantiza a esos mismos ciudadanos que la justicia quiere ejercerse de modo independiente e imparcial"14. Las normas éticas de una profesión constituyen las mejores prácticas. Aplicadas a los jueces, son las normas o principios que todos los jueces deben intentar desarrollar y a las que deberían aspirar.

Por el contrario, las normas que regulan la disciplina de los jueces dan lugar a un procedimiento disciplinario. Y un procedimiento disciplinario deberá incoarse por una conducta infractora grave y evidente, de modo que no pueda ser enunciada como la desobediencia a las normas profesionales definidas en directrices o principios.

Por supuesto que existe una relación entre responsabilidad disciplinaria y código ético profesional ${ }^{15}$. Pero debería existir una regulación temporalmente

\footnotetext{
13 D’Ambrosio (2006), p. 192.

14 SAIZ (2012), p. 21.

15 Lo que se debe destacar es que responsabilidad disciplinaria y responsabilidad ética de acuerdo a un código ético o de buenas prácticas, no son lo mismo. Por ello no puede compartirse lo que ha sostenido parte de la doctrina nacional al respecto. En efecto, José Francisco García, sostiene que "en
} 
distinta al camino que se ha trazado en países como Chile y en la tradición continental. Primero debería existir un código ético o de buenas prácticas que defina los valores de la institución que merecen especial protección, así como los principios éticos y las reglas de conducta que deben rodear la actuación de los jueces. Todo ello es algo que la propia judicatura debería darse. Y luego de ello, y tomando como base ese código de buenas prácticas, el legislador debería regular minuciosamente en la ley cuáles conductas de los jueces serán consideradas ilícitas y traerán aparejada una sanción.

La deontología judicial "no debe servir únicamente a los objetivos disciplinarios; en otras palabras, el comportamiento no conforme a las exigencias deontológicas no debe necesariamente conducir a la sanción"16.

En definitiva, siguiendo a Jiménez Asencio ${ }^{17}$, sin perjuicio del relativo parentesco que pueda haber entre un código ético o de buenas prácticas y un régimen de responsabilidad disciplinaria, la finalidad y objetivos de ambos son muy diferentes.

Dejando de lado la comparación entre responsabilidad disciplinaria y un código de buenas prácticas o ético, corresponde detenerse y preguntarse por el segundo aspecto enunciado, esto es si estamos frente a una actividad de tipo jurisdiccional (jurisdicción disciplinaria) o bien bajo una modalidad de derecho administrativo sancionador de los superiores jerárquicos respecto a sus subordinados.

Esta es quizás la aclaración más importante que debe realizarse, pues de lo que se determine se siguen importantes consecuencias. Una primera aproximación podría indicarnos que la responsabilidad de los jueces debería seguir la misma lógica de la responsabilidad de los otros funcionarios públicos, con especial referencia a los funcionarios de la Administración del Estado. Bajo esta lógica, será normal entender que bajo las definiciones de conductas indebidas determinadas por la ley, el superior jerárquico del funcionario podrá realizar las investigaciones que corresponden y aplicar la sanción que corresponda. En este sentido, sería legítimo que una Corte de Apelaciones o la Corte Suprema realice una investigación interna y, si encuentra mérito, aplique la sanción al juez denunciado.

materia disciplinaria se debe avanzar en la confección de un Código de Ética Judicial". García (2009), p. 117; a su vez Juan Enrique Vargas ha señalado que se debe modificar el sistema disciplinario de los jueces chilenos, lo que debe comprender, entre otras cosas, "una definición clara a través de un Código de Ética Judicial de las conductas sancionables". VARGAS (2007), p. 119.

${ }^{16}$ Canivet y Joly-Hurard (2004), p. 117.

17 Jiménez Asencio (2012), p. 41. 
En esta situación, como actividad de tipo administrativo, deberá adecuarse a las exigencias de un debido proceso sustantivo.

Otra posición dirá que la responsabilidad disciplinaria de los jueces es una actividad de tipo jurisdiccional y, como tal, a dicha actividad se le exigirán todas las garantías de un debido proceso procesal.

Ahora bien, a estas dos hipótesis podría agregarse una tercera, que dirá que no es actividad administrativa ni jurisdiccional, sino una actividad atípica y especial. Se habla en muchos casos de un procedimiento disciplinario jurisdiccionalizado ${ }^{18}$.

La distinta calificación del procedimiento disciplinario tiene importancia sobre muchos aspectos. Si se lo considera actividad jurisdiccional o un procedimiento jurisdiccionalizado, será mayor la exigencia de imparcialidad del juzgador y deberá articularse un sistema adecuado de impugnación de las decisiones disciplinarias. Por el contrario, si se lo considera actividad de tipo administrativo al interior de la judicatura, menores serán las exigencias de imparcialidad de quien impone las sanciones y el sistema de impugnaciones será distinto, entre otros aspectos.

En este escenario, postulamos que a los jueces no se les puede aplicar el mismo estatuto que al resto de los funcionarios públicos. Al respecto ha señalado la Corte Constitucional italiana, en su sentencia № 100 de 1981, que respecto a los jueces el fundamento del poder disciplinario no puede buscarse, como para los empleados públicos, en la relación de supremacía especial que liga a los dependientes de la Administración Pública, debiendo excluirse una relación de este tipo respecto a los jueces, los que están sujetos solo a la ley, en virtud del artículo 101 de la Constitución italiana.

En virtud de este fallo, se ha entendido en Italia que la responsabilidad disciplinaria de los jueces se entiende bajo la relación que tienen los jueces con el Estado-persona, del cual son funcionarios ${ }^{19}$. Por ello, se debe excluir una concepción de la responsabilidad disciplinaria de los jueces como un instrumento en virtud del cual el orden judicial determina las conductas de los funcionarios bajo una óptica corporativa.

Como orden independiente, no pueden los otros órganos del Estado controlar la conducta de los jueces, aplicando sanciones. Pero bajo una mirada de independencia interna y para evitar lógicas corporativas, la aplicación de sanciones no puede quedar entregada a los superiores jerárquicos de los jueces. Eso claramente afecta la independencia de los jueces al interior de la judicatura ${ }^{20}$.

\footnotetext{
18 BiOndi (2006), pp. 268 y ss.

19 ZANON (2009), p. 123.

20 En el derecho chileno no es mucha la doctrina que se ha referido a este punto. Véase al respecto García (2009), p. 89; también Horvitz (2007), p. 141. Con menos énfasis véase también lo que ha sostenido VARGAS (2007), p. 120.
} 
El valor constitucional de la independencia de los jueces, que se relaciona también con una concepción difusa de la judicatura, exige un trato diferente en esta materia para jueces y los funcionarios de la Administración.

En materia judicial tenemos un poder difuso y exigencias de independencia interna. Ello no existe respecto de los funcionarios de la Administración. Por ello, los jueces no pueden quedar en la misma situación que los funcionarios de la Administración del Estado que sí pueden ser investigados y sancionados por sus superiores jerárquicos.

Como se trata de una responsabilidad como funcionarios del Estado, corresponderá a la ley establecer cuáles son las conductas que traen aparejada una sanción. Y luego corresponderá a un órgano independiente e imparcial aplicar las sanciones en el caso concreto. Esa función corresponde en muchos países a una sección del Consejo General del Poder Judicial o a especiales tribunales disciplinarios para tal efecto, como es el caso de Alemania.

Dicho lo anterior, la responsabilidad disciplinaria de los jueces debe ser entendida bajo una óptica de derecho sancionador por un lado y luego de actividad jurisdiccional ${ }^{21}$; una jurisdicción disciplinaria ${ }^{22}$. O puede entenderse también como una actividad especial que en la etapa de aplicación de las sanciones tiene que estar jurisdiccionalizada íntegramente.

Como derecho sancionador, deberán aplicarse las garantías sustanciales de un derecho penal o derecho sancionador del Estado. Luego, como actividad juzgadora, deberá aplicarse a la responsabilidad disciplinaria el estatuto mínimo de un debido proceso. Y matizadamente se aplicarán algunas garantías que forman parte del debido proceso penal.

Conviene por tanto distinguir y analizar aquellas garantías de orden sustancial y aquellas procesales del debido proceso.

\subsection{Garantías sustanciales del derecho disciplinario judicial}

La Constitución de 1980 establece algunas garantías sustanciales aplicables al derecho penal. Esas mismas deben aplicarse al derecho disciplinario judicial.

Las garantías sustanciales que reconoce la Constitución son:

a) La ley no podrá presumir de derecho la responsabilidad penal (art. 19 $N^{\circ} 3$ inciso $\left.7^{\circ} \mathrm{CPR}\right)$.

21 Giacobbe y Nardozza (1996), p. 117; Pizzorusso (1990), p. 217; D’Ambrosio (2006), p. 204.

22 Nicola Graziano afirma categóricamente que el procedimiento disciplinario de los jueces italianos es un procedimiento jurisdiccional y está regulado por las normas del Código de Procedimiento Penal en la medida que sean compatibles. Graziano (2013), p. 308. 
b) Ningún delito se castigará con otra pena que la que señale una ley promulgada con anterioridad a su perpetración, a menos que una nueva ley favorezca al afectado (art. $19 \mathrm{~N}^{\circ} 3$ inciso $8^{\circ} \mathrm{CPR}$ ).

c) Ninguna ley podrá establecer penas sin que la conducta que se sanciona esté expresamente descrita en ella (art. $19 \mathrm{~N}^{\circ} 3$ inciso $9^{\circ} \mathrm{CPR}$ ).

Analizados los preceptos legales del Código Orgánico de Tribunales, es posible aseverar que la garantía expresada en la letra c) no es respetada con algunas de las regulaciones sobre los ilícitos disciplinarios que realiza ese cuerpo legal. Existe una falta de tipicidad de algunas conductas prohibidas en la ley que traen aparejadas sanciones para los jueces.

Además, se verá que algunas conductas prohibidas a los jueces comportan una afectación indebida al ejercicio de sus derechos fundamentales.

Finalmente, deberá tenerse presente que por exigencias de independencia interna de los jueces, lo que es tributario de una concepción difusa del poder judicial, la forma cómo los jueces interpretan y aplican la ley a un caso concreto no debe ser objeto de sanción disciplinaria. Vamos a analizar en ese orden el tema de las garantías sustanciales en los ilícitos disciplinarios.

\subsubsection{Falta de tipicidad de los ilícitos disciplinarios}

Para analizar el problema de falta de tipicidad de los ilícitos disciplinarios, vamos a examinar dos preceptos que nos parecen paradigmáticos de esta problemática. Uno tiene rango constitucional y el otro legal. El primero es el artículo 80 inciso $3^{\circ} \mathrm{CPR}$ y el otro es el 544 COT.

El artículo 80 inc. $3^{\circ} \mathrm{CPR}$ señala que "[...]la Corte Suprema por requerimiento del Presidente de la República, a solicitud de parte interesada, o de oficio, podrá declarar que los jueces no han tenido buen comportamiento y, previo informe del inculpado y de la Corte de Apelaciones respectiva, en su caso, acordar su remoción por la mayoría del total de sus componentes. Estos acuerdos se comunicarán al Presidente de la República para su cumplimiento".

Esta disposición no tipifica meridianamente qué conductas de los jueces pueden significar que no han tenido buen comportamiento o, dicho de otro modo, que han tenido mal comportamiento.

Se puede objetar este argumento señalando que el artículo 337 COT desarrolla las hipótesis de mal comportamiento, con lo cual el legislador ordinario habría salvado la falta de tipicidad de las conductas por las cuales la Corte Suprema puede remover a un juez de su cargo.

Sin embargo, esta complementación legal a la vaguedad de la cláusula constitucional debe ser rechazada por dos tipos de argumentaciones. En primer lugar, si bien el artículo 337 COT establece algunos casos que constituyen una presunción de derecho que un juez no tiene buen comportamiento, ese artículo 
legal no puede entenderse que colma y desarrolla íntegramente el artículo 80 inc. $3^{\circ} \mathrm{CPR}$. La Corte Suprema no está atada solo a los casos que enumera el artículo 337 COT.

Por otra parte, el artículo 337 COT también presenta hipótesis normativas vagas o atípicas. Piénsese en el numeral $3^{\circ}$ : "si fuere corregido disciplinariamente más de dos veces en cualquier espacio de tiempo, por observar una conducta viciosa, por comportamiento poco honroso o por negligencia habitual en el desempeño de su oficio".

Por su parte, el artículo 544 COT señala que las facultades disciplinarias de la Corte Suprema y Cortes de Apelaciones se deben especialmente ejercitar respecto de los funcionarios del orden judicial "cuando por irregularidad de su conducta moral o por vicios que les hicieren desmerecer en el concepto público comprometieren el decoro de su ministerio". Esta es una cláusula clásica del derecho disciplinario judicial de derecho continental. Ella presenta tanto problemas de falta de tipicidad como de contenido moralizante incompatible con una organización jurídica que se basa, entre otros principios, en un pluralismo ético o ideológico ${ }^{23}$. Esta fórmula elástica e indeterminada procede del ordenamiento judicial napoleónico y ha sido objeto de múltiples críticas en la doctrina comparada ${ }^{24}$.

Se ha señalado que este tipo de cláusulas no es compatible con un sistema sancionador bajo el principio de legalidad ${ }^{25}$, pues el órgano juzgador termina por asumir un rol de creador del código disciplinario, asumiendo así una "función paralegislativa" ${ }^{26}$. Si la ley no prefigura en términos más o menos claros cuál es la conducta prohibida o, dicho en otros términos, si el precepto normativo carece de densidad suficiente, es claro que quien tiene que aplicar el precepto a un caso concreto termina por crear la conducta prohibida. En eso consiste la denuncia de una "función paralegislativa".

Asimismo, los destinatarios desconocen con anterioridad cuáles son las conductas prohibidas, contrariando fuertemente el principio de seguridad jurídica $^{27}$. Esta crítica la ha asumido la Corte Europea de Derechos Humanos, pues condenó con fecha 2 de agosto de 2001 al Estado italiano por una decisión de

\footnotetext{
23 Bordalí (2010), p. 77.

${ }^{24}$ Giuliani y Picardi (1995), p. 80. Rebuffa (1993), p. 105. Picardi (1979), pp. 1.489 y 1.503; Rentería (2002), p. 183.

${ }^{25}$ Alessandro Pizzorusso sostiene que el procedimiento de medidas disciplinarias contra los jueces asume un carácter jurisdiccional muy cercano a uno de tipo penal que exige, entre otras cosas, legalidad y tipicidad de las conductas que pueden acarrear sanciones a los jueces. Pizzorusso (1990), p. 217.

${ }^{26}$ Giacobbe y Nardozza (1996), p. 134.

27 Rossi (2001), pp. 79 y 80.
} 
la sección disciplinaria del Consejo Superior de la Magistratura, la que había sancionado a un juez por pertenecer a la masonería, sin que ese juez supiera que tal hecho fuese una conducta prohibida y sujeta a sanción.

Un sistema de cláusulas elásticas e indeterminadas afecta la independencia de los jueces, pues éstos no saben cuáles conductas están permitidas y cuáles prohibidas $^{28}$. Esa situación les puede restar libertad de juicio al momento de fallar un asunto. Pero, además, se puede prestar para un uso parcial y selectivo del instrumento sancionador, pudiendo utilizarse como un arma con fines de condicionar el ejercicio jurisdiccional, o para discriminar, intimidar o extorsionar a los jueces ${ }^{29}$, especialmente cuando esos jueces puedan pertenecer a determinadas corrientes gremiales o políticas ${ }^{30}$. Por estas críticas es que países como Italia reformaron el sistema de responsabilidad disciplinaria de los jueces, mediante la Ley $\mathrm{N}^{\circ} 150$ de 2005, procediéndose entre otras cosas a una mayor tipificación de las conductas sancionables. No se trata de una tipificación absolutamente rígida, sino tendencialmente rígida ${ }^{31}$. Esa ley luego fue modificada en algunos aspectos por el decreto legislativo $\mathrm{N}^{\circ} 109$ de 23 de febrero de 2006, el que Sergio Bartole describe como un texto normativo donde se enumeran las sanciones aplicables a los jueces, junto a una puntual y detallada tipificación legislativa, distinguiendo entre los ilícitos disciplinarios cometidos en el ejercicio de las funciones y aquellos fuera del ejercicio de las funciones, así como también como consecuencia de la comisión de delitos ${ }^{32}$

El modelo napoleónico de responsabilidad disciplinaria, como el que existe en Chile, pone acento sobre el sujeto en cuyos términos se es responsable (Corte Suprema o Cortes de Apelaciones entre nosotros). Se trata de un instrumento conformador de conductas lícitas según las orientaciones de otros sujetos ${ }^{33}$. Este modelo presupone la existencia de una relación de subordinación de los jueces y, en consecuencia, una clara reducción de su independencia respecto del superior.

Si la ley estableciera con precisión las conductas sancionadas, el sujeto sería responsable en términos de lo que el poder legislativo haya dispuesto; se estaría en este caso frente a un instrumento sancionatorio por actos ilícitos, lo cual parece no presentar mayores problemas

\footnotetext{
28 Оветто (1999), р. 243.

${ }^{29}$ ERbani (2006), p. 298.

30 ZANON y BIONDI (2006), p. 167.

31 Graziano (2013), p. 289.

32 Bartole (2008), p. 73.

33 ZaNON y Biondi (2006), p. 160.
} 
Nuestro Tribunal Constitucional no ha estado ajeno a este problema. En Recurso de Inaplicabilidad deducido por una Secretaria Judicial que actuaba como Juez Suplente, se impugnó por resultar a su juicio contrario a la Constitución un conjunto de preceptos del Código Orgánico de Tribunales. Entre los preceptos cuestionados destacaban los artículos 541 inc. $2^{\circ}, 539$ inc. $2^{\circ}, 557,558,536,537,542$ y $544 \mathrm{~N}^{\circ} 4$ COT, pues a juicio de la requirente con ellos se afectaba el principio de tipicidad.

El Tribunal Constitucional, por sentencia de fecha 31/8/2007, rol № 747 , determinó que el principio de tipicidad propio del derecho penal no es aplicable en sede de responsabilidad disciplinaria de los jueces. No obstante, señaló que ello no significa que la Constitución tolere que un juez pueda ser sancionado por una conducta que él mismo no estuvo en condiciones de reconocer con antelación como reprochable. Son otros principios constitucionales, no el de tipicidad penal, sostiene el Tribunal Constitucional, los que exigen previsibilidad de las conductas que acarrean responsabilidad, como el principio de independencia judicial y el de un justo y racional procedimiento (Considerando 27).

No es compartible el criterio sustentado en este fallo por el Tribunal Constitucional. Desde luego con este tipo de cláusulas se afecta el principio constitucional de independencia judicial, pero también se afecta la garantía de la tipicidad de las conductas que acarrean sanciones para los jueces. A su vez, no es necesario invocar respecto a estos preceptos una vulneración del debido proceso. La afectación del debido proceso de los jueces está en otras cláusulas del Código Orgánico de Tribunales.

Dialogando con esta sentencia de nuestro Tribunal Constitucional, se podría sostener que no es necesario que exista total tipicidad en estos ilícitos, debido a que siempre han existido sistemas de responsabilidad basados en la atipicidad, como sucede con la responsabilidad civil extracontractual. Lo mismo puede decirse de la disciplina de los funcionarios de la Administración del Estado. Sin embargo, se puede contestar tal refutación señalando que existen diferencias en términos de garantía entre los modelos de responsabilidad penal, disciplinaria y civil. Esas diferencias se centran en las consecuencias sancionatorias, esencialmente patrimoniales en materia civil, prevalecientemente personales para los otros modelos.

De este modo, en la responsabilidad disciplinaria, y obviamente en la penal también, las garantías deben ser mayores que en el campo civil y la tipificación debe ser exigida en términos estrictos. Y en el campo de jurisdicción disciplinaria, la tipificación debe ser mayor que la que existe en materia de control disciplinario de los funcionarios de la Administración por sus superiores jerárquicos, pues está en juego el valor de la independencia e imparcialidad judiciales. 


\subsubsection{Afectación en el ejercicio de los derechos fundamentales de los jueces en algunos ilícitos disciplinarios del Código Orgánico de Tribunales}

Cómo se decía, preceptos como el 544 COT no solo presentan un problema de falta de tipicidad de las conductas prohibidas, sino que también tienen un contenido moral incompatible con un Estado de Derecho basado en el pluralismo ideológico y en la vigencia de los derechos fundamentales de todas las personas y funcionarios públicos, incluidos los jueces. ¿Qué podemos entender por irregularidad de la conducta moral de un juez o funcionario judicial? ¿Cómo debemos entender un vicio que le hiciere desmerecer en el concepto público?

Este tipo de normas son la expresión positiva de un modelo de juez asumido mayoritariamente en el pasado en los estados de tradición católica, es decir, el modelo de un "juez sacerdote" ${ }^{134}$. En este modelo se espera que el juez sea un hombre bueno, verdadera imagen de Cristo. Dicha concepción del juez constituye un flagrante atentado a una concepción moderna del Estado de derecho, que se sustenta en la libertad, en el pluralismo y en el respeto de los derechos fundamentales, entre los que se reconocen el derecho al libre desarrollo de la personalidad, a la vida privada, a la honra, a la libertad de expresión, de reunión, asociación, entre otros.

El recurso a determinadas normas de contenido moral en el derecho disciplinario de los jueces solo es entendible en un régimen jurídico premoderno. En efecto, en el medioevo y bajo el Estado Absoluto, la legitimidad del poder no está en la ley. En el caso del Rey su poder tiene orígenes divinos. En el caso de los jueces su legitimidad está dada por la corrección moral de sus vidas. Sus fallos serán respetados y acatados en la medida que inspiren respeto por la bondad de quien los emite. Por eso se construye una idea de juez como hombre ejemplar, un juez que es expresión en su forma y fondo de los valores del mundo católico.

Y esa es la concepción que fundamenta muchos artículos de nuestro Código Orgánico de Tribunales, que se inspira a su vez en una legislación española premoderna.

La relación entre el ejercicio de los derechos fundamentales de los jueces y la salvaguarda de valores constitucionales y legales de la independencia e imparcialidad judiciales no es de fácil composición. Se ha entendido mayoritariamente que, por exigencias del adecuado desarrollo de la función judicial, la ley puede limitar en algunos casos estos derechos fundamentales de los jueces. Pero el legislador deberá actuar razonablemente de modo tal que la limitación de estos derechos fundamentales sea necesaria y dirigida a proteger los valores

34 Gimeno (1981), p. 64. 
o bienes constitucionales en referencia. Si no están en juego la independencia e imparcialidad judiciales, la limitación de derechos fundamentales se hace ilegítima.

Los jueces son titulares de derechos fundamentales como todas las personas que habitan el territorio nacional. El legislador podrá limitar el ejercicio de esos derechos constitucionales para hacerlos compatibles con otros valores constitucionales, como lo son los de independencia e imparcialidad judiciales. Ese legislador deberá operar con criterios restrictivos e inspirado en el principio pro libertate.

Sobre el sistema de responsabilidad disciplinaria y los derechos fundamentales de los jueces chilenos se pronunció, aunque tangencialmente, la Corte Interamericana de Derechos Humanos en sentencia de fecha 24 de febrero de 2012 recaída en la causa Atala Riffo y niñas vs. Chile. De conformidad con el fallo de la Corte Interamericana, la indagación disciplinaria realizada por la Corte de Apelaciones de Temuco respecto de la jueza Karen Atala se llevó a cabo de un modo tal que afectó su derecho fundamental a la vida privada y a un tribunal imparcial.

Cuando nos referimos a la violación de derechos fundamentales en el derecho chileno, en este caso respecto a las personas que ejercen la función jurisdiccional, estoy considerando aquellos derechos reconocidos en la Constitución Política de la República como aquellos contenidos en tratados internacionales sobre derechos fundamentales ratificados por el Estado chileno y que se encuentren vigentes (art. $5^{\circ}$ inciso $2^{\circ} \mathrm{CPR}$ ). De especial relevancia serán aquellos derechos fundamentales reconocidos en la Convención Americana de Derechos Humanos, pues ellos son plenamente justiciables, de conformidad al amplio reconocimiento competencial que el Estado chileno ha realizado a la Corte Interamericana de Derechos Humanos.

Sin entrar en la discusión sobre el valor que tienen dichos tratados internacionales en el derecho chileno, los derechos ahí reconocidos son derecho obligatorio y su no reconocimiento por el Estado chileno acarrea responsabilidad jurídica.

Para efectos de este trabajo, señalaré que tanto la Constitución Política de la República como los tratados internacionales sobre derechos humanos, con especial referencia a la Convención Americana de Derechos Humanos, exigen al Estado chileno regular de un mejor modo la organización y función judiciales. Todo ello lo resumiré en la idea de exigencias constitucionales.

\subsubsection{Contenido de los ilícitos disciplinarios}

Una cuestión importante a determinar es si el modo como los jueces inter-

pretan y aplican la ley a un caso concreto puede ser considerado una actividad 
que podría dar lugar a una sanción disciplinaria. Nuestra posición es que salvo hipótesis de delitos funcionarios, como cohecho o prevaricación, la decisión jurisdiccional de los jueces no debe dar lugar nunca a una sanción disciplinaria. No debe entenderse esa actividad como una hipótesis de ilícito disciplinario.

Este rechazo a considerar como una hipótesis de ilicitud disciplinaria el ejercicio jurisdiccional se justifica por los siguientes argumentos. Los jueces inferiores no solo están debidamente capacitados sino que además lo están de la mejor manera para dar por probados los hechos e interpretar las reglas y principios jurídicos aplicables a dichos hechos. Los tribunales superiores se encuentran en una situación de desventaja frente a ese juez de base para desarrollar la función jurisdiccional, pues su conocimiento de los hechos y del derecho aplicable a ellos será siempre menos incisivo.

Otro argumento. Juzgar es una actividad compleja que comporta necesariamente un margen de discrecionalidad tanto en la determinación de los hechos del caso como del material normativo que se aplicará a esos hechos. Y la sentencia judicial se funda en argumentaciones inspiradas en la composición de intereses, la coherencia, la congruencia y la racionalidad ${ }^{35}$. Todo este entramado de difícil articulación y definición hace muy complejo determinar por otro tribunal que hubo un error judicial que amerite una sanción.

Ahora bien, lo anterior no se opone a que tribunales superiores de justicia puedan conocer recursos que los justiciables interpongan en contra de las resoluciones de los jueces ${ }^{36}$. Y los tribunales superiores podrán modificar o anular las sentencias de los tribunales inferiores. Ello podrá producirse: 1) por diversidad de criterios entre los distintos tribunales en la apreciación de las pruebas y en la interpretación del derecho; 2 ) por error por parte del tribunal en el establecimiento de los hechos y en la interpretación del derecho y 3) por error grave o inexcusable (dolo o culpa) por parte de un tribunal en el establecimiento de los hechos y en la interpretación del derecho ${ }^{37}$. En este último caso estamos frente a una hipótesis en que tal error debe o puede dar lugar a una responsabilidad penal por parte del o los jueces.

Por el contrario, las dos primeras situaciones ( 1 y 2 ) no deberían traer aparejada sanción o consecuencia negativa alguna para el juez o los jueces, pues de lo contrario desaparece radicalmente la independencia de los jueces. Esto

\footnotetext{
35 BAIRATI (2013), p. 5.

${ }^{36}$ Un sistema de recursos procesales no obedece a un esquema de jerarquías piramidales, sino solo a una garantía de pronunciamientos jurisdiccionales múltiples. Por ello el juez de apelación o casación no puede prescribir a priori los contenidos de un pronunciamiento, sino que solo puede valorar a posteriori la decisión impugnada. SILVESTRI (2004), p. 11.

37 Este aspecto ya ha sido tratado en Bordalí (2013), p. 107.
} 
es así, entre otras razones, porque no es posible entender que exista un sistema deductivo de valoración de la prueba, es decir, un sistema que proporcione una certeza absoluta si se ha partido de una premisa correcta. Asimismo, ello es consecuencia además de que no existe una actividad silogista-mecanicista de la interpretación y aplicación de un precepto jurídico. En eso consiste precisamente la independencia del juez; es precisamente aquí donde radica la esencia de la independencia del juez ${ }^{38}$.

Cosa distinta será el caso de sentencias judiciales que carezcan de motivación o cuando no haya ninguna ilación lógica entre los hechos establecidos en la sentencia y la fundamentación jurídica, o entre la parte expositiva de la sentencia y la resolutiva, entre otras posibilidades. Esos defectos en la forma y construcción de la sentencia sí podrían dar lugar a sanciones disciplinarias, si el legislador así lo estima. Pero todo ello es muy distinto a sancionar a un juez por cómo ha dado por establecidos unos hechos en el proceso judicial o por cómo ha interpretado el derecho aplicable en un determinado proceso judicial. En estas materias el juez de la instancia es soberano absoluto.

Con un criterio más general, los jueces solo podrían ser sancionados disciplinariamente por todos aquellos actos jurídicos procesales que no estén referidos al acto decisorio en su mérito ${ }^{39}$. Se podría volver a esa distinción antigua entre el error in iudicando y el in procedendo, con la aclaración que las cuestiones referidas a la falta de motivación de la sentencia o motivaciones incompletas o incorrectas son cuestiones referidas al procedimiento (in procedendo) y no al mérito. Como tal, sí podrían ser posibles de sancionar disciplinariamente.

El acto decisorio del juez que no sería sancionable disciplinariamente comprendería la valoración de las pruebas rendidas en el proceso y la interpretación y aplicación de las normas jurídicas aplicables a esos hechos.

Esta posición que se sustenta aquí implica derogar la institución del Recurso de Queja de los artículos 545 y siguientes COT. La propuesta que se realiza acá es que la causal del Recurso de Queja, esto es faltas o abusos graves contenidos en resoluciones judiciales y referidas al mérito de lo decidido, se traslade y se subsuma en las hipótesis de delitos funcionarios, como los de cohecho, prevaricación y otros. Y respecto a cuestiones procedimentales, podría seguir rigiendo el Recurso de Queja como control disciplinario, con tal que se tipifiquen las conductas constitutivas de faltas o abusos graves. Pero tal como está

\footnotetext{
38 Martínez (2004), p. 341; Senese (2004), pp. 32 y ss.

39 Como ha sostenido el Tribunal Supremo español en sentencia de 11 de diciembre de 1998, es posible concebir un sistema de responsabilidad disciplinaria de los jueces, en la medida que con ella no se limite o coaccione el ejercicio independiente de la función jurisdiccional y no se incida en las valoraciones jurídicas que determinan la resolución o el fallo.
} 
regulado actualmente el Recurso de Queja, con la posibilidad de sancionar a los jueces disciplinariamente por cómo han valorado las pruebas e interpretado el derecho y sin que se tipifiquen las conductas prohibidas, éste no se ajusta a las exigencias actuales de una justicia independiente.

\subsection{Garantías del debido proceso en la jurisdicción disciplinaria judicial}

Hemos sostenido anteriormente que con la responsabilidad disciplinaria de los jueces estamos frente a un tipo de derecho sancionador y luego una actividad jurisdiccional, la jurisdicción disciplinaria o al menos una actividad particular jurisdiccionalizada. De conformidad a esa naturaleza jurisdiccional, deberá aplicarse a ella todas las garantías de un debido proceso. El tema que es más discutible será determinar si se le aplican o no las garantías de un debido proceso penal.

Comenzaré señalando que existe cierto consenso, en la doctrina ${ }^{40}$ y jurisprudencia nacionales ${ }^{41}$ y comparada, en que al derecho administrativo sancionador se le aplican matizadamente las mismas garantías de un debido proceso penal. No se trata de una jurisdicción propiamente penal, pero forma parte de la misma lógica del ius puniendi estatal, y como tal se le aplican la mayoría de las garantías sustanciales y procesales del derecho penal. Partiendo de esa base, a una actuación jurisdiccional que puede imponer sanciones a los sujetos pasivos, en este caso a los jueces, es meridianamente claro que ese procedimiento disciplinario debe regirse por las exigencias de un debido proceso, con las similares exigencias de un debido proceso penal.

La Constitución vigente no utiliza la expresión debido proceso, pero no por un olvido o un explícito deseo de no reconocer esta garantía a las personas, sino por no emplear una denominación que tiene sus orígenes en el derecho anglosajón (due process of law). Por este motivo, el constituyente de 1980 optó por usar la expresión equivalente de "racional y justo procedimiento" (art. 19 $N^{\circ} 3$ inciso $\left.6^{\circ} \mathrm{CPR}\right)$.

¿Qué garantiza el debido proceso a todos los habitantes del territorio nacional? Evidentemente nos encontramos con una cláusula de contenido indeterminado que debe ser colmada por el legislador o por los tribunales de justicia. La Comisión de Estudio de una Nueva Constitución (en adelante CENC), en sus sesiones 101 a 103, dejó claro que este derecho fundamental se refería a garantías

40 Cordero (2014), pp. 430 y ss.; Bermúdez (2013), p. 427; Vergara (2004), p. 139.

${ }^{41}$ La aplicación matizada al Derecho Administrativo sancionador de las garantías penales sustanciales ha sido asumida por la jurisprudencia de nuestro Tribunal Constitucional. Un análisis exhaustivo de esa jurisprudencia puede analizarse en el trabajo de ArANCIBIA (2015). 
tales como el emplazamiento de las partes, el examen y objeción de la prueba rendida, la existencia de recursos procesales, la fundamentación de las sentencias, etcétera, enumeración que tiene un mero sentido ejemplar, puesto que el objetivo de la cláusula "racional y justo procedimiento" era el concebir un principio de carácter constitucional que debía ser determinado en cada caso concreto por aquellos órganos competentes para realizar esa labor.

Ahora bien, nuestro texto constitucional, aparte de la criolla cláusula general del debido proceso, reconoció algunas específicas garantías que tradicionalmente han formado parte de un debido proceso, como lo son el derecho de defensa jurídica en juicio (art. $19 \mathrm{~N}^{\circ} 3$ inc. $2^{\circ} \mathrm{CPR}$ ) y el derecho a un juez ordinario predeterminado por la ley (art. $19 \mathrm{~N}^{\circ} 3$ inc. $5^{\circ} \mathrm{CPR}$ ). A esas garantías deben agregarse todas las otras que reconocen los tratados internacionales sobre derechos humanos ratificados por el Estado chileno y que se encuentren vigentes (art. $5^{\circ} \mathrm{CPR}$ ).

Entre las garantías propias de un debido proceso, con especial referencia a un proceso penal, se encuentran: El derecho a un tribunal independiente e imparcial; el derecho a un tribunal ordinario predeterminado por la ley; el derecho a un proceso legalmente tramitado; el derecho a un juicio oral y público; el derecho a un proceso sin dilaciones indebidas; el derecho a una sentencia motivada y el derecho de defensa, que comprende a su vez varios derechos, como lo son: el derecho a disponer de un abogado o derecho a la defensa en un sentido técnico; el derecho a conocer de la acusación y de todos los actos del proceso; el principio acusatorio, el derecho a presentar defensas y alegaciones o derecho a contradecir; el derecho a utilizar los medios de prueba legales; el derecho a no ser obligado a declarar contra sí mismos y el derecho a ser presumido inocente. Existen otros derechos como el derecho a los recursos procesales, que puede discutirse si son parte del debido proceso o más bien de un derecho a la tutela judicial, discusión en la que no se puede entrar ahora por falta de espacio y ser inoportuno.

A continuación pasaré a revisar algunos de los aspectos del debido proceso donde existen dudas sobre si el proceso disciplinario chileno se ajusta a él. Esos aspectos a analizar dicen relación con el derecho a un tribunal independiente e imparcial; el respeto del principio acusatorio; el derecho a un proceso legalmente tramitado; el derecho a un juicio oral y público y algunos aspectos del derecho de defensa.

\subsubsection{El tribunal disciplinario y el derecho a un tribunal independiente $\mathrm{e}$ imparcial}

El primer contenido del debido proceso es el derecho a un tribunal independiente e imparcial. Este derecho lo exige el artículo 8.1 de la Convención Americana de Derechos Humanos. 
Independencia e imparcialidad deben ser consideradas como situaciones conectadas pero con sustantividades diferentes. Un juez que es amigo de una de las partes del juicio podrá ser considerado parcial en esa causa pero no necesariamente falto de independencia. La independencia se refiere a un aspecto o faceta más estática u orgánica frente a lo funcional o procesal que implica la imparcialidad. La independencia de los jueces constituye una condición de existencia de la imparcialidad.

Para el Tribunal Europeo de Derechos Humanos (en adelante TEDH), asume especial relevancia para garantizar la independencia judicial el modo de designación de los jueces y la duración del mandato judicial, así como la existencia de previsiones normativas idóneas para tutelar al órgano jurisdiccional contra presiones externas, según se concluye de la sentencia de esta corte europea de fecha $1^{\circ}$ de octubre de 1982, caso Piersack contra Bélgica.

A nivel americano, la Corte Interamericana de Derecho Humanos (en adelante $\mathrm{CIDH}$ ) ha señalado que la falta de independencia judicial, que conlleva la falta de imparcialidad, constituye una violación del artículo $8^{\circ} \mathrm{CADH}$, así como una evidente carencia de igualdad para uno de los litigantes. Agrega que la independencia de la judicatura, como órgano, es fundamento esencial de la justicia que debe impartir el Estado, así como la independencia personal de los jueces es indispensable para asegurar su imparcialidad y hacer posible que puedan ejercer sus funciones con autonomía y sin presiones y ambas -independencia de la judicatura e independencia de los jueces- garantizan el derecho a un debido proceso de todas las personas sometidas a juicio, cualquiera sea la naturaleza de ésta ${ }^{42}$.

Los casos en que la CIDH ha dispuesto que determinados tribunales de países signatarios de la $\mathrm{CADH}$ atentan contra el derecho a un tribunal independiente, son aquellos en que se cuestiona la composición de esos tribunales, como ocurre con los militares.

A su vez, la imparcialidad considerada subjetivamente dice relación con el posicionamiento personal de los jueces en los términos de las partes de una causa judicial. Se habla de una consideración del fuero interior de los jueces, que debe considerarse imparcial mientras no se demuestre lo contrario. Se ha dicho que la imparcialidad subjetiva, cual derecho fundamental de los justiciables, comporta una garantía que permite que un juez sea apartado de un caso concreto cuando existan sospechas objetivamente justificadas. Es decir, debe tratarse de conductas exteriorizadas y apoyadas en datos objetivos que permitan afirmar que el juez no es ajeno a la causa o que permitan temer que, por

42 Abreu (2007), p. 643. 
cualquier relación con el caso concreto, no utilizará como criterio de juicio el previsto por la ley, sino otras consideraciones ajenas al ordenamiento jurídico.

El criterio subjetivo de la imparcialidad ha sido declarado por el Tribunal Europeo de Derechos Humanos en sentencias como la de 26 de octubre de 1984 en la causa De Cubber contra Bélgica, y luego en otras como Fey de 24 de febrero de 1993, Remli, de 23 de abril de 1996 y Gregory, de 25 de febrero de 1997.

Corresponderá a la parte que se lamenta de la parcialidad del magistrado demostrarla, probando en concreto que la disposición anímica o psicológica del juez y su conducta exteriorizada son síntomas de falta de imparcialidad.

Por otra parte, la imparcialidad considerada objetivamente toma en consideración la relevancia de aquellas condiciones exteriores que pueden comprometer o perjudicar la administración imparcial de la justicia. En esta perspectiva importa mucho la apariencia de imparcialidad de los jueces. La imparcialidad objetiva apunta también a la necesaria confianza que los órganos judiciales deben dar a los ciudadanos y, sobre todo, a los acusados por delito. Sentencias relevantes en esta materia del TEDH son las de fecha 24 de mayo de 1989 (Hauschildt con Dinamarca) y la de fecha 25 de junio de 1992 (Thorgeir Thorgeirson con Islandia).

Con la imparcialidad objetiva no se trata ya de que el juez haya exteriorizado convicción personal alguna ni haya tomado partido previo, sino que estamos frente a un juez que no ofrece garantías suficientes para excluir toda duda legítima al respecto. Por eso, en esta perspectiva, importan sobremanera las consideraciones de carácter funcional y orgánico, pues determinan si, por las funciones que se le asignan al juez en el proceso, puede ser visto como un tercero ajeno a los intereses que en él se ventilan ${ }^{43}$.

Para poder determinar si el tribunal de la disciplina judicial cumple con estas exigencias de independencia e imparcialidad, se debe determinar en primer lugar cuál es ese tribunal.

Para los tribunales ordinarios y especiales que forman parte del Poder Judicial, como tribunales de primera instancia o subalternos de las Cortes de Apelaciones, el tribunal disciplinario es la Corte de Apelaciones respectiva. El artículo 535 COT así lo establece. El artículo 538 COT autoriza a las Cortes a ejercer de oficio este poder. Respecto de las Cortes de Apelaciones, el tribunal disciplinario es la Corte Suprema, según lo expresa el artículo 540 inc. $3^{\circ}$ COT.

Sin embargo, este orden podría alterarse si la Corte Suprema asume como tribunal disciplinario, pues está facultada para ejercer la jurisdicción correccional, disciplinaria y económica sobre todos los tribunales de la Nación (art. 540 inciso $\left.1^{\circ} \mathrm{COT}\right)$.

${ }^{43}$ Sobre este aspecto véase Bordalí (2010), p. 90 y ss. 
Debe tenerse presente además el artículo 541 COT, que establece que "la Corte Suprema tiene respecto de sus miembros y de su fiscal judicial las facultades que corresponden a las Cortes de Apelaciones por los artículos 535 y 539 , inciso primero". Esto quiere decir que los Ministros de la Corte Suprema también tienen responsabilidad disciplinaria y el tribunal que conoce es la propia Corte.

Agrega el inciso $2^{\circ}$ del mismo precepto que "la Corte Suprema puede, además, siempre que lo juzgare conveniente a la buena administración de justicia, corregir por sí las faltas o abusos que cualesquiera jueces o funcionarios del orden judicial cometieren en el desempeño de su ministerio, usando para ello de las facultades discrecionales que corresponden a las Cortes de Apelaciones con arreglo a los artículos 536 y 537".

A estas disposiciones debe agregarse la del artículo $631^{\circ}$ letra c). Esta disposición establece como competencia de las Cortes de Apelaciones, conocer en única instancia "de los recursos de queja que se deduzcan en contra de los jueces de letras, jueces de policía local, jueces árbitros y órganos que ejerzan jurisdicción, dentro de su territorio jurisdiccional". Esta competencia es atribución del pleno de la respectiva Corte (art. 66 inc. $4^{\circ} \mathrm{COT}$ ). Asimismo, debe tenerse presente el artículo 98 COT, que establece que corresponde a las salas de la Corte Suprema, $7^{\circ}$ "De los recursos de queja, pero la aplicación de medidas disciplinarias será de la competencia del tribunal pleno".

Habrá de tenerse presente además los preceptos que regulan las visitas que pueden realizar a los tribunales subalternos los ministros de las Cortes de Apelaciones y de la Corte Suprema.

Tenemos de este modo que el tribunal disciplinario de los jueces de letras y demás jueces de primera instancia es la Corte de Apelaciones respectiva. Respecto de los ministros de Cortes de Apelaciones el tribunal disciplinario es la Corte Suprema. Para los ministros de la Corte Suprema el tribunal disciplinario es ese mismo tribunal. Debe entenderse que estos tribunales disciplinarios conocen por regla general en pleno.

¿Pueden ser considerados independientes e imparciales los tribunales disciplinarios de los jueces chilenos? Desde luego estos tribunales cumplen con las garantías orgánicas para considerarlos independientes, tanto externa como internamente. Analizada la vigencia de la debida imparcialidad, hay que mencionar que la vertiente subjetiva no opera en términos generales ni abstractos, por lo que deberá ser analizada caso a caso. Respecto a la imparcialidad objetiva surgen dudas de si ella es respetada en estos casos.

Al respecto, se debe comentar que los tribunales disciplinarios cumplen distintos roles respecto a los jueces que pueden enjuiciar. Funcionan como cortes superiores para efectos del ejercicio jurisdiccional, conociendo de los recursos de apelación, nulidad o casación que se interpongan respecto de las resoluciones de los tribunales 
inferiores. Asimismo, los tribunales disciplinarios cumplen tareas administrativas relacionadas con la progresión en la carrera de los jueces, procediendo a calificar a esos jueces periódicamente. Ese ejercicio de distintos roles respecto de los jueces objeto de control disciplinario, puede comportar una especie de incompatibilidad que afecta a la debida imparcialidad del tribunal disciplinario.

Pongamos un ejemplo. Una Corte de Apelaciones ha conocido de varias apelaciones respecto de sentencias de un determinado juez de letras. En general ha acogido esas apelaciones revocando los fallos de primera instancia del juez de letras, pues no comparte el criterio jurídico sustentado por éste. Asimismo, dicha Corte ha calificado en la última oportunidad de manera Regular al respectivo juez. $\mathrm{Y}$ acto seguido, se formula una denuncia contra ese juez por una supuesta infracción disciplinaria. Esa misma Corte de Apelaciones deberá resolver al final del procedimiento disciplinario si aplica una sanción o no a ese juez. Es evidente que la Corte puede tener un prejuicio respecto del juez denunciado, pues no comparte su criterio jurídico en las apelaciones que ha conocido y además no lo ha calificado anualmente con las mejores calificaciones. Se produce en este caso lo que la doctrina ha llamado incompatibilidad, o bien opera la fuerza de la prevención. Es probable que esa Corte no pueda conocer de esa causa con total imparcialidad ${ }^{44}$, pues ya ha emitido juicios respecto a ese juez.

Por otra parte, en materia de recursos procesales, se produce una doble vulneración a las garantías procesales y orgánicas en el Acta 129-2007 de la Corte Suprema. En efecto, el artículo 8.2. h) CADH reconoce a todas las personas el "derecho de recurrir del fallo ante juez o tribunal superior". Ese tribunal debe ser imparcial por un lado y además superior del que dictó la sentencia en materia disciplinaria.

Los problemas de falta de imparcialidad ya han sido analizados. Pero ahora se agrega que en el caso que la sanción disciplinaria la imponga la Corte Suprema, no existe un recurso ante un tribunal superior, sino el de reposición ante la misma Corte Suprema (art. 13 inciso $2^{\circ}$ Acta 129-2007). Eso no se condice con las exigencias de un debido proceso regulado en la Convención Americana de Derechos Humanos.

\footnotetext{
${ }^{44}$ Juan Enrique Vargas ha señalado que el control disciplinario de los jueces debe ser reelaborado, buscando un sistema claro, transparente, objetivo y que sea percibido como legítimo por todos, lo que supone, entre otras cosas, el establecimiento de un procedimiento que garantice la imparcialidad del juzgador y el derecho de defensa, lo que a su vez implica la "creación de una entidad independiente al juzgador encargada de tramitar e investigar las quejas contra los funcionarios y de deducir las acusaciones que dieren lugar". Más adelante agrega: el "establecimiento de una entidad independiente encargada de juzgar a los funcionarios". De lo que expone Vargas debería asumirse que sostiene que el actual sistema de sanciones disciplinarias que imponen las Cortes de Apelaciones y la Corte Suprema no garantiza la imparcialidad del juzgador. VARGAS (2007), pp. 119 y 120.
} 


\subsubsection{El proceso disciplinario y el principio acusatorio}

En materias penales debe existir una contienda entre dos posiciones contrapuestas, esto es acusador y acusado, que tiene que resolver un juez como tercero imparcial. Se exige una neta distinción entre las funciones de acusador y juzgador, que deben recaer en órganos y sujetos diversos. Quien acusa debe ser un sujeto distinto al que juzga. No puede realizarse un juicio sin previa acusación sostenida por un sujeto distinto del juez. Además, la sentencia dictada en el juicio tiene que tener correlación con la acusación. Esta correlación tiene dos dimensiones básicas: subjetiva y objetiva. La acusación determina a quien con exclusividad se va a enjuiciar. Nadie puede ser condenado sin que previamente ha sido acusado ante el tribunal. Desde el punto de vista objetivo, el hecho punible debe ser mantenido inmutablemente desde que ha sido calificado y la sentencia judicial solo puede referirse a él, sin que se puedan agregar después de la calificación otros hechos ${ }^{45}$. Esto es lo esencial en un proceso organizado bajo el principio acusatorio.

El principio acusatorio es un modelo de proceso judicial que permite asegurar de mejor modo los derechos procesales que forman parte de un proceso definido como debido proceso.

Dicho lo anterior, hay que mencionar que el artículo 538 COT autoriza a las Cortes a ejercer de oficio el poder disciplinario. Esa facultad reconocida en la ley a las Cortes de Apelaciones choca frontalmente con el principio acusatorio. Y al afectarse el principio acusatorio, se ponen en entredicho las garantías procesales de los justiciables y que forman parte de un debido proceso.

\subsubsection{El proceso disciplinario y el derecho a un proceso legalmente tramitado}

Hemos sostenido que la actividad desarrollada por las cortes chilenas para sancionar a un juez es una actividad jurisdiccional o una actividad sui generis íntegramente jurisdiccionalizada. Debido a esa naturaleza jurisdiccional, es competencia exclusiva del legislador regular el proceso por el cual se va a determinar la responsabilidad del juez acusado.

La exigencia de ley para regular los procesos jurisdiccionales se extrae de varios preceptos constitucionales. En primer lugar, el artículo $19 \mathrm{~N}^{\circ} 3$ inciso $6^{\circ}$ CPR que establece: "Toda sentencia de un órgano que ejerza jurisdicción debe fundarse en un proceso legalmente tramitado. Corresponderá al legislador establecer siempre las garantías de un procedimiento y una investigación racionales y justos".

${ }^{45}$ Sobre este aspecto véase Bordalí (2016), p. 206. 
Luego tenemos el artículo 63 números 3 y 20 CPR. "Sólo son materias de ley: (...) las que son objeto de codificación, sea civil, comercial, procesal, penal u otra"; y "toda otra norma de carácter general y obligatoria que estatuya las bases esenciales de un ordenamiento jurídico".

He aquí un punto crítico en esta materia, pues el Congreso Nacional no ha regulado los aspectos centrales de ese procedimiento disciplinario. Esa inactividad del ente legislativo llevó a la Corte Suprema a regular el procedimiento disciplinario de los jueces y funcionarios judiciales, por medio de las Actas $N^{\circ} 129-2007$, la que se encuentra modificada por el Acta No 168-2007.

Es entendible que la Corte Suprema haya regulado mediante estas actas el procedimiento disciplinario judicial, pero no por ello lo hace legítimo desde el punto de vista constitucional. Solo el legislador está facultado para regular estos procedimientos. Y llama la atención por lo demás que el tribunal dicte estas actas o acuerdos, pues no existe base constitucional ni legal que lo autorice a dictarlas.

Si bien desde el año 2005 puede entenderse que la Corte Suprema, las Cortes de Apelaciones y el Tribunal Calificador de Elecciones tienen una atribución constitucional para dictar Autos Acordados, en virtud de la introducción ese año del artículo $93 \mathrm{~N}^{\circ} 2 \mathrm{CPR}$, atribución que tiene un reconocimiento muy anterior en el Código Orgánico de Tribunales para esas cortes, lo cierto es que ni la Constitución ni la ley les reconocen, ni a la Corte Suprema ni a las Cortes de Apelaciones, la facultad para dictar otros instrumentos normativos como actas o acuerdos.

Llama poderosamente la atención que en el Acta 129-2007 de fecha 1 de agosto de 2007 se hable en varios pasajes de acuerdo y no de auto acordado y luego, días después, con fecha 11 de septiembre del mismo año, en el Acta 168-2007, la misma Corte dispuso la "modificación del auto acordado sobre procedimiento para investigar responsabilidad disciplinaria de jueces y funcionarios". La utilización de los términos actas, acuerdos y luego autos acordados no se ajusta a lo prescrito en la Constitución y las leyes y su uso confuso no se ajusta a los valores de juridicidad y seguridad jurídica que inspiran y deben inspirar a nuestro Estado de Derecho.

En definitiva, el proceso disciplinario de los jueces, por exigencias constitucionales, debe estar regulado por ley y no por autos acordados, actas o acuerdos de los tribunales superiores de justicia. El Congreso Nacional debe regular esta materia.

\subsubsection{El proceso disciplinario y el derecho a un juicio oral y público}

En la Convención Americana de Derechos Humanos la publicidad, y luego se podría deducir la oralidad, solo es exigida para los procesos penales. El 
artículo 8.5 garantiza que el proceso penal debe ser público, salvo en lo que sea necesario para preservar los intereses de la justicia.

Tenemos de este modo que en el derecho chileno el juicio penal debe ser oral y público. La publicidad y oralidad en materias no penales solo es exigida por el Pacto Internacional de Derecho Civiles y Políticos, no así por la CADH. La mayor exigencia de publicidad y oralidad en el orden penal que en el civil corresponde por lo demás a un cierto consenso en la doctrina y en el derecho comparado. Las exigencias del debido proceso, y en este caso la publicidad y oralidad del proceso, son mucho más incisivas en materia penal que civil. De este modo, un juicio penal escrito -donde la publicidad se ve dificultada- es contrario a las exigencias constitucionales y a los tratados de derechos fundamentales vigentes en Chile.

El derecho a un juicio público admite límites, los que debe establecer el legislador. Como toda ley que desarrolla o, en este caso, limita derechos fundamentales, deberá ser respetuosa del contenido esencial del derecho. Por otra parte, al tratarse de límites a un derecho fundamental, la resolución judicial que restrinja el ejercicio del derecho deberá estar motivada, de forma tal que la razón determinante de la decisión pueda ser conocida por el afectado ${ }^{46}$.

El proceso disciplinario debe ajustase en muchos aspectos a las exigencias de un proceso penal. Los juicios penales deben ser orales y públicos por exigencias de un debido proceso. El procedimiento disciplinario regulado en el Acta 129-2007 no es oral ni público.

Originalmente, el procedimiento de investigación por ilícitos disciplinarios de la judicatura chilena era siempre reservado, reserva que podía ser dejada sin efecto para el denunciado, treinta días después de habérsele comunicado su apertura, si así lo resuelve el investigador de oficio o a petición del denunciado (art. $8^{\circ}$ ). Este artículo fue modificado por la Corte Suprema a petición de la Asociación Nacional de Magistrados, y en el Acta 168-2007 se matizó esta reserva absoluta, disponiendo que el investigador podrá disponer que determinadas diligencias y actuaciones sean reservadas incluso respecto del investigado, cuando considere que ello es necesario para la eficacia del procedimiento. Esa facultad se limita en su ejercicio solo a dos veces durante la investigación y su vigencia en cada caso no puede ser superior a diez días.

Es importante precisar un aspecto acá. La regulación del Acta 129-2007 no permite hablar de un proceso jurisdiccional. El Acta se articula bajo la forma de una investigación o sumario de tipo administrativo. Por ello, tampoco se puede distinguir, como lo hacía el proceso penal inquisitivo chileno anterior a la reforma

\footnotetext{
${ }^{46}$ Sobre este aspecto véase Bordalí (2016), p. 210.
} 
del año 2000, entre una etapa sumarial secreta y luego un plenario o proceso penal inspirado en una idea de publicidad para alguna de sus actuaciones.

El legislador debería regular de mejor forma este procedimiento, disponiendo que la publicidad sea la regla general y el secreto o reserva la excepción. Pueden existir razones para no exigir total publicidad ni oralidad al procedimiento disciplinario judicial, pero el principio de publicidad debe seguir rigiendo en los aspectos más relevantes.

\subsubsection{El proceso disciplinario y el derecho de defensa}

Este derecho está reconocido en su faceta más general por nuestra Constitución, en su artículo $19 \mathrm{~N}^{\circ} 3$ inciso $2^{\circ}$ : "Toda persona tiene derecho a defensa jurídica en la forma que la ley señale y ninguna autoridad o individuo podrá impedir, restringir o perturbar la debida intervención del letrado si hubiere sido requerida". Luego el inciso $3^{\circ}$ agrega: "La ley arbitrará los medios para otorgar asesoramiento y defensa jurídica a quienes no puedan procurárselos por sí mismos. En el inciso $4^{\circ}$ del mismo artículo se asegura que "toda persona imputada de delito tiene derecho irrenunciable a ser asistida por un abogado defensor proporcionado por el Estado si no nombrare uno en la oportunidad establecida por la ley".

El derecho de defensa asegura a las partes la posibilidad de sostener argumentalmente sus respectivas pretensiones y rebatir los fundamentos que la parte contraria haya podido formular en apoyo de las suyas, pero sin que sea necesario que de facto tenga lugar una efectiva controversia argumental entre los litigantes que, por razones de diversa índole, puede no producirse. Esto quiere decir que no se afecta este derecho en concreto, si se ofrece a los litigantes la posibilidad real de ser oídos, con independencia de que éstos hagan uso o no de esta posibilidad.

En orden a conseguir que la defensa procesal se pueda llevar a cabo, es de especial relevancia que los órganos jurisdiccionales permitan a las partes su defensa procesal mediante la correcta ejecución de los actos de comunicación establecidos por el legislador.

El derecho de defensa comprende no solo la asistencia de un abogado elegido libremente por el justiciable o el abogado de oficio que según la ley nombre el tribunal o la autoridad competente; comprende también el derecho a defenderse personalmente. Sin embargo, a ello no se opone que el legislador pueda exigir la comparecencia ante el tribunal con el patrocinio de un abogado y con la representación de un mandatario judicial, abogado o estudiante de los cursos más avanzados de derecho, según disponga el legislador.

En materia exclusivamente penal, las personas tienen derecho para poder defenderse correctamente, que exista comunicación previa y detallada de la 
acusación formulada en su contra (art. 8.2 b) CADH. El imputado tiene derecho a conocer cabalmente los hechos que se le imputan y de los cargos que se le imputan, para así poder defenderse de manera contradictoria. Lo esencial es conocer los hechos considerados punibles. Su calificación jurídica puede variar durante el procedimiento.

En esta materia también existe lo que se denomina prohibición de reformatio in peius. Esto significa que la situación del condenado recurrente, fijada en la sentencia recurrida, no puede verse agravada por la resolución del tribunal de apelación, casación, nulidad o del recurso que haya previsto el legislador ante un tribunal superior (art. 8.2. h) $\mathrm{CADH}$.

En relación con el derecho de defensa debe mencionarse el derecho a utilizar los medios de prueba pertinentes. No aparece reconocido expresamente en ningún texto internacional ni en nuestra Constitución. Pero hay que entender que una de las manifestaciones o posibilidades concretas de la defensa judicial consiste en la posibilidad de que se admitan o practiquen pruebas. El legislador tiene plena facultad para configurar el ejercicio de este derecho, pero de un modo tal que permita su ejercicio real y efectivo. En este poder configurador, el legislador puede autorizar al juez que impida que las partes soliciten pruebas impertinentes, esto es, que no tengan relación con el objeto litigioso del proceso o el tema decidendi. Lo mismo sucede en caso de pruebas ilícitas, es decir, obtenida con infracción de derechos fundamentales de algún sujeto. Por último, la prueba debe rendirse en los tiempos y oportunidades procesales que fije el legislador.

Con relación a la prueba y solo con connotación penal, el art. 8.2. e) CADH asegura al acusado por delito el derecho de interrogar a los testigos y de obtener la comparecencia de otros testigos o peritos.

Por su parte, el artículo 8.2. g) CADH reconoce el derecho a no ser obligado a declarar contra sí mismo ni a declararse culpable ${ }^{47}$.

En relación con una efectividad en la defensa del inculpado, el artículo 8.2 $\mathrm{CADH}$ asegura el derecho a ser presumido inocente. La presunción de inocencia también puede ser considerado un derecho autónomo, pero sin duda que su reconocimiento facilita la defensa del inculpado, si se considera que tiene un claro impacto en la distribución de la carga de la prueba entre los intervinientes del enjuiciamiento criminal.

Veamos cómo se relaciona el procedimiento disciplinario de los jueces chilenos con las exigencias de un derecho de defensa. En primer lugar, se debe señalar que la naturaleza de investigación sumaria o sumario administrativo y no de proceso jurisdiccional, consta en la declaración que hacen los ministros

${ }^{47}$ Este aspecto ya ha sido tratado en Bordalí (2016), pp. 204 y ss. 
de la Corte Suprema en el Acta No 168-2007. En efecto, en el párrafo segundo del Acta se lee: "Que si bien esta Corte Suprema estima conveniente introducir enmiendas a las disposiciones contenidas al aludido procedimiento, debe señalar que éste regula el proceso de formación de un acto disciplinario y que si bien debe garantizar racionalmente el derecho de defensa del magistrado o funcionario judicial que pueda haber incurrido en faltas a sus deberes y prohibiciones, no constituye un juicio entre partes".

Este es el supuesto que el legislador debe cambiar, de modo de hacer efectiva la responsabilidad disciplinaria de los jueces en virtud de un proceso disciplinario y no en virtud de una investigación administrativa, de un superior a un funcionario subordinado.

La doctrina más autorizada proponía décadas atrás avanzar hacia la jurisdiccionalización de la responsabilidad disciplinaria de los jueces, recomendando entre otros aspectos: 1) Legitimar activamente para iniciar los procedimientos disciplinarios a un órgano externo del aparato judicial, como podría ser el Defensor del Pueblo; 2) Reconocer el derecho de defensa del juez inculpado, con derecho a defenderse con abogado y en juicio público, similar a un proceso penal de tipo acusatorio ${ }^{48}$.

Desde luego, el sujeto que realiza una investigación disciplinaria no puede tener vínculos de subordinación o dependencia orgánica con el tribunal disciplinario, algo que no garantiza el procedimiento regulado en el Acta 129-2007.

A su vez, lo regulado en el artículo $15^{\circ}$ del Acta 129-2007 no se muestra respetuoso con el derecho de defensa, en la parte que dispone que "toda resolución que imponga una medida disciplinaria, sobresea o absuelva al investigado, será comunicada a la Corte Suprema, aunque no deduzca apelación a su respecto". Este resabio monárquico que es el trámite de la consulta o apelación obligatoria o de oficio, como atribución de la Corte Suprema, no se ajusta a las exigencias de un debido proceso.

En definitiva, las regulaciones legales y las que emanan de la propia Corte Suprema no se ajustan completamente a las exigencias de un debido proceso.

\section{Perspectivas de reforma constitucional y al Código Orgánico de Tribunales en materia de responsabilidad disciplinaria de los jueces}

La responsabilidad disciplinaria de los jueces chilenos requiere de reformas constitucionales y legales para adecuarla a las necesidades de un Estado de Derecho que se construye sobre la base de la total independencia e imparcialidad

\footnotetext{
${ }^{48}$ Véase estas propuestas del grupo de estudio formado bajo el alero de la Universidad de Perugia en Italia en PICARDI (1979), pp. 1503 y ss.
} 
de los jueces y sobre la plena vigencia de los derechos fundamentales de todos, con especial consideración de un debido proceso.

De particular importancia es que el legislador modifique la Constitución Política de la República en lo que se refiere a las potestades de la Corte Suprema para remover a los jueces (art. 80 inc. $3^{\circ} \mathrm{CPR}$ ) y en la atribución a esa misma corte de la superintendencia correccional sobre todos los jueces de la Nación, con las exclusiones que la propia Constitución realiza (art. 82 CPR).

Por otra parte, se requiere modificar todo el articulado del Código Orgánico de Tribunales en lo que se refiere al órgano que conoce de las denuncias disciplinarias; el órgano requirente o legitimado activo; las conductas ilícitas y los recursos que proceden contra las resoluciones que imponen sanciones, entre los aspectos más relevantes.

Esas reformas deben caminar por encomendar el control de la disciplina de los jueces a un órgano que no sea la Corte Suprema ni las Cortes de Apelaciones. Será una decisión política de las fuerzas mayoritarias del Congreso Nacional determinar qué órgano puede realizar adecuadamente el control de la disciplina de los jueces.

Esta propuesta de separar funcionales jurisdiccionales y aquellas no jurisdiccionales que actualmente ejerce la Corte Suprema, como ocurre con el control disciplinario de los jueces inferiores, ya cuenta con el apoyo de nuestro máximo tribunal. En efecto, en el Acta No 186-2014, la Corte Suprema se manifestó favorablemente a la separación de dichas funciones. El voto de mayoría de la Corte Suprema señaló que debía crearse un órgano interno al Poder Judicial para desempeñar esas labores no jurisdiccionales. Algunos Ministros fueron de la idea de que este órgano interno tuviese una integración mixta, esto es con miembros del Poder Judicial y extraños al mismo. Pero un número importante de ministros, como voto de minoría, estuvo por crear un órgano externo al Poder judicial, de composición mixta, quien debía desarrollar esas labores no jurisdiccionales.

Las alternativas respecto a la disciplina judicial pueden ser varias. La mayoritaria en el derecho comparado pasa por crear un órgano de dirección o gobierno de la judicatura, y dentro de él se puede crear una sección o tribunal disciplinario. Me refiero a un órgano del tipo Consejo General de la Judicatura.

Otra posibilidad consiste en crear especiales tribunales disciplinarios que pueden tener una integración con miembros completamente externos a la judicatura, o bien con una composición mixta, es decir, con miembros que pertenecen al Poder Judicial y que suspenden su ejercicio en esos tribunales de los que forman parte mientras formen parte del tribunal disciplinario, a los que se unen otros miembros externos a la judicatura.

Desde luego, tanto el órgano del tipo Consejo General de la Judicatura o los tribunales disciplinarios deberían tener representación regional. 
Se deberá separar claramente las funciones de investigación y acusación, y de conocimiento y resolución de la acusación. Ese órgano acusador e investigador puede ser en la organización judicial actual la Fiscalía Judicial ${ }^{49}$. Otra opción, si el legislador optara por la creación de un órgano del tipo Consejo General de la Judicatura, podría consistir en la creación de una sección de ella que investigue los ilícitos disciplinarios y, si encuentra base, realice la acusación correspondiente. A ese órgano investigador podrán hacerle llegar denuncias contra los jueces aquellos particulares que sean o hayan sido parte en alguna gestión judicial, los jueces y demás funcionarios del Poder Judicial y el Ejecutivo a través de algún funcionario del Ministerio de Justicia. Además, el órgano acusador podrá iniciar de oficio la investigación.

Los ilícitos disciplinarios tendrán un plazo de prescripción y para hacerse valer. Dos años puede ser un plazo razonable para entender que el ilícito ha prescrito, o bien que el plazo para ejercer la acción disciplinaria caducó. Cuando el ilícito se contenga en una sentencia judicial, el plazo se contará desde que la resolución fue notificada a las partes o desde que quede ejecutoriada.

Por otra parte, se necesitan reformas al Código Orgánico de Tribunales donde se tipifiquen adecuadamente las conductas que pueden comportar una sanción disciplinaria. Esas conductas deben estar lo más detalladas posibles y no deben incluir el cómo los jueces interpretan y aplican la ley a un caso concreto. Ese tipo de ilícito debe quedar entregado al Derecho Penal para aquellos casos en que los jueces dan una interpretación o aplicación de la ley errónea o arbitraria, con dolo o culpa (hipótesis de prevaricación).

Los ilícitos disciplinarios, que tienen que estar completamente detallados en la ley, pueden consistir en maltrato físico o de palabra a los funcionarios judiciales y abogados que litigan ante ellos; no asistencia al trabajo e incumplimiento de los horarios de trabajo; no realización del trabajo jurisdiccional como la ausencia injustificada a las audiencias; hacer comentarios públicos de una causa judicial pendiente en el sentido que pueda constituir un adelantamiento de la decisión; no motivar las sentencias judiciales; motivaciones incompletas o incoherentes; participar en actividades políticas partidistas, etc.

En relación con las conductas prohibidas, éstas no deben tener un contenido moralizador y referido a la vida privada de los jueces, como las referencias a conducta viciosa, faltas a la moral, conducta indecorosa, entre otras. Habrá de tenerse en consideración si otras prohibiciones o limitaciones actualmente existentes para los jueces, referidas al ejercicio de derechos fundamentales como la libertad de expresión, derecho de reunión y de asociación, se encuentran justificadas y en

\footnotetext{
${ }^{49}$ En igual sentido véase VARGAS (2007), p. 119.
} 
concordancia con los valores constitucionales que permitirían esas prohibiciones o limitaciones, como son los de independencia e imparcialidad judiciales.

En lo que dice relación con el proceso disciplinario, se debe mencionar que éste debe estar completamente regulado por ley. No puede haber ninguna otra fuente normativa que regule este tipo de proceso, como podría ser un Reglamento o Decreto del Ejecutivo, o un Auto Acordado, Acta o Acuerdo de un tribunal de justicia.

Respecto al proceso disciplinario, como ya se dijo, éste no puede ser iniciado por el propio órgano que conocerá de él en definitiva. Debe regir el principio acusatorio.

Los jueces acusados tendrán el pleno derecho de defensa, pudiendo designar abogado patrocinante y mandatario judicial. Podrán acompañar todos los medios de prueba disponibles, bajo un sistema de prueba libre. Eso incluye a su vez una libre valoración de los medios de prueba. La sentencia deberá contener una valoración pormenorizada de cada uno de los medios de prueba presentados en el proceso.

El procedimiento será por regla general público, oral o escrito.

La sentencia definitiva que dicte el tribunal disciplinario podrá ser recurrida ante otro órgano o sección superior. Si el tribunal disciplinario forma parte de una sección del Consejo General de la Judicatura, puede encomendarse al pleno de ese Consejo conocer de los recursos que se dicten contra la sección disciplinaria que resolvió. Si se trata de un tribunal disciplinario, debe haber otro tribunal superior que conozca del recurso.

Para terminar, se debe señalar que el procedimiento disciplinario de los jueces chilenos está regulado actualmente contrariando garantías sustanciales y procesales exigidas por la Constitución Política de la República y tratados internacionales sobre derechos humanos.

De acuerdo con este diagnóstico, corresponde que el constituyente y luego el legislador ordinario actúen, de modo que se regule el proceso disciplinario de los jueces de conformidad con las exigencias constitucionales. Sin duda las modificaciones constitucionales son más difíciles desde un punto de vista de mayorías políticas y de tiempos, pero no existe excusa para que el Congreso Nacional no modifique ahora mismo el Código Orgánico de Tribunales en lo que sea necesario para que algunos aspectos del control disciplinario de los jueces sean legítimos desde un punto de vista constitucional. Es el Congreso Nacional quien tiene atribuida la competencia en esta materia y no la Corte Suprema ni ningún otro órgano del Estado.

\section{BibLiOGRAFíA}

Abreu, Alirio (2007): "Independencia judicial (jurisprudencia de la Corte Interamericana de Derechos Humanos", en: Anuario de Derecho Constitucional Latinoamericano (Año 13), pp. 639-651. 
Arancibia, Tamara (2015): "Análisis crítico de la jurisprudencia del Tribunal Constitucional en materia de sanciones administrativas", en: Cuadernos del Tribunal Constitucional, ( $\left.{ }^{\circ} 58\right)$.

BAIRATI, Lorenzo (2013): La responsabilità per fatto del giudice in Italia, Francia e Spagna, fra discipline nazionali e modelo europeo (Nápoles, Edizioni Scientifiche Italiane).

Bartole, Sergio (2008): Il potere giudiziario (Bolonia, Il Mulino).

Bermúdez, Jorge (2013): “Fundamento y límites de la potestad sancionadora administrativa en materia ambiental", en: Revista de Derecho (Valparaíso), (XL, 2013, primer semestre), pp. 421-447.

Bıondı, Francesca (2006): La responsabilitá del magistrato (Milán, Giuffrè).

Bordalí, Andrés (2003): "Independencia y responsabilidad de los jueces", en: Revista de Derecho (Valdivia), (Vol, XIV), pp. 159-174.

Bordalí, Andrés (2010): La independencia judicial en el derecho chileno (Santiago de Chile, LegalPublishing).

Bordalí, Andrés (2013): "Los jueces al acecho", en: Anuario de Derecho Público 2013 (Santiago de Chile, Universidad Diego Portales), pp. 97-109.

Bordalí, Andrés (2016): Derecho jurisdiccional (Valdivia, Ediciones Derecho Austral).

Canivet, Guy y Joly-Hurard, Julie (2004): La deontologie des magistrats (París, Dalloz).

Cordero, Eduardo (2014): "Los principios que rigen la potestad sancionadora de la Administración en el derecho chileno", en: Revista de Derecho (Valparaíso), (XLII, primer semestre), pp. 399-439.

D’Ambrosıo, Vito (2006): "La disciplina dei magistrati", en: Paciotti, Elena (coordinadora), Per un nuovo ordinamento giudiziario (Florencia, Passigli editori), pp. 191-212.

ERBANI, Stefano (2006): "Gli illeciti disciplinari del magistrato", en: Carcano, Domenico (coordinador), Il nuovo ordinamento giudiziario (Milán,Giuffrè), pp. 297-325.

FerRAjOLI, Luigi (1997): Derecho y razón. Teoría del garantismo penal, segunda edición (Madrid, Trotta).

García, José Francisco (2009): "Corte Suprema y gobierno judicial: un programa de reformas", en: Actualidad jurídica (№ 20, Tomo I), pp. 81-121.

GiacobBe, Giovanni y NardozZA, Massimo (1996): Potere e responsabilitá nel' ordine giudiziario (Milán, Giuffrè).

Gimeno, Vicente (1981): Fundamentos del Derecho Procesal (Madrid, Civitas). 
GIUlIANI, Alessandro y PICARDI, Nicola (1995): La responsabilità del giudice (Milán, Giuffrè).

Grazıano, Nicola (2013): Ordinamento giudiziario (Roma, Dike Editrice).

Horvitz, María Inés (2007): "Independencia de los jueces y estructura judicial", en: Atria, Fernando y Couso, Javier (coordinadores), La judicatura como organización (Santiago de Chile, Expansiva, Instituto de Estudios Judiciales), pp. 125-142.

JIMÉNEZ AsENCIO, Rafael: "Imparcialidad judicial: su proyección sobre los deberes (código de conducta) y derechos fundamentales del juez", en: Saiz, Alejandro (coordinador), Los derechos fundamentales de los jueces (Madrid, Marcial Pons), pp. 27-44.

Martínez, María Luz (2004): La independencia judicial (Madrid, Centro de Estudios Constitucionales).

Oвerto, Giacomo (1999): "Les droits et les obligations des juges. Leur responsabilité disciplinaire", en: AA. VV. L'indipendenza de la giustizia, oggi (Milán, Giuffrè), pp. 233-260.

PICARDI, Nicola (1979): "Problemi attuali della responsabilità del giudice", en: Rivista Trimestrale di Diritto Processuale Civile.

Pizzorusso, Alessandro (1990): L'organizzazione della giustizia in Italia. La magistratura nel sistema político e istituzionale (Turín, Einaudi).

Rebuffa. Giorgio (1993): La funzione giudiziaria (Turín, Giappichelli).

ReNTERíA, Adrián (2002): Discrecionalidad judicial y responsabilidad, segunda edición (México D.F., Fontamara).

Rossi, Nello (2001): "Il potere disciplinare", en: Mazzamuto, Salvatore (coordinador), Il Consiglio Superiore della Magistratura. Aspetti costituzionali e prospettive di riforma, (Turín, Giappichelli), pp. 69-101.

SAIZ, Alejandro (2012): "Estudio introductorio", en: Saiz, Alejandro (coordinador), Los derechos fundamentales de los jueces (Madrid, Marcial Pons), pp. 9-25.

SCHefold, Dian (2004): "Potere giurisdizionale e posizione del giudice in Germania", en: Gambino, Silvio (coordinador), La magistratura nello stato costituzionale. Teoria ed esperienze a confronto (Milán, Giuffrè), pp. 251-266.

SenESE, Salvatore (2004): "La riforma dell'ordinamento giudiziario", en: Del Canto, Francesco y Romboli, Roberto (coordinadores), Contributo al dibattito sull'ordinamento giudiziario (Turín, Giappichelli), pp. 15-40.

SILVESTRI, Gaetano (2004): "La reforma dell'ordinamento giudiziario", en: Gambino, Silvio (coordinador), La magistratura nello stato costituzionale. Teoria ed esperienze a confronto (Milán, Giuffrè), pp. 3-14. 
VARGAS, Juan Enrique (2007): "Alternativas para estructurar el gobierno judicial respetando la independencia de los jueces", en: Atria, Fernando y Couso, Javier (coordinadores), La judicatura como organización (Santiago de Chile, Expansiva, Instituto de Estudios Judiciales), pp. 97-124.

VerGara, Alejandro (2004): "Esquema de los principios del Derecho Administrativo sancionador", en: Revista de Derecho (Coquimbo), (Año 11, N²), pp. 137-147.

ZANON, Nicoló (2009): "Azione disciplinare e modelo di giudice", en: Campanelli, Giusseppe (coordinador), Controllare i giudici (Cosa, chi, come, perché). Atti del convegno di studi - Lecce, febbraio 2008 (Turín, Giappichelli), pp. 121-135.

ZANON, Nicolò y BIONDI, Francesca (2006): Il sistema costituzionle della magistratura (Bolonia, Zanichelli). 